\title{
Picturing Carnal Temptation and Sin in Italian Post-Tridentine Art
}

\section{Minna Hamrin}

Minna Hamrin, Picturing Carnal Temptation and $\mathrm{Sin}$ in Italian Post-Tridentine Imagery (Ábo Akademi University Press, 2018), http:!lurn fil! URN:ISBN:978-951-765-914-7.

\section{LECTIO.}

"Att samtala med kvinnor utan att bli nersolkad av deras syndighet är lika lätt som att gå på glödande kol utan att sveda sina fötter". Med dessa ord uppmanade heliga Franciskus av Assisi i mitten av 1200-talet sina följare att möjligaste mån undvika all kvinnlig kontakt. Kvinnan, som härstammade från Eva och därmed indirekt var orsaken till människans miserabla tillstånd på jorden ansågs oren och oberäknelig.
I en patriarkal religionskultur, där kyskhet sågs som en dygd och köttslig lust som en inkörsport till synd, blev kvinnan, föremålet för den manliga åtrån, också stämplad som en fresterska, rentav skadlig för den troende mannen.

Jag har under drygt sex års tid studerat bilder föreställande manliga helgon, däribland sankt Franciskus, som möter, frestas av och sedermera motstår kvinnliga gestalters diverse amorösa förslag. De undersökta bilderna är tillverkade efter det Tridentinska konciliet, även kallad den katolska reformationen, en tid då den katolska kyrkan genom ett ökat antal moralregler försökte begränsa folkets möjligheter till skörlevnad.

Det var inledningsvis inte självklart att just 1600-talets bildkonst skulle ligga till grund för denna avhandling. Frestelsemotivet har förekommit inom den kristna bildkonsten sedan medeltiden, det avslöjar en väl etablerad misogyni som går att finna i äldre skrifter och bilder. Jag kunde dock redan i ett relativt tidigt skede se, att i samband med den katolska reformationen och det efterföljande seklet uppdaterades den äldre medeltida ikonografin och nya frestelsescener introducerades. Valet att koncentrera forskningen till denna tidsperiod föll sig därför naturligt.

I avhandlingen undersöker jag hur frestelsescenerna visuellt kommunicerar den katolska kyrkans striktare inställning till kroppsliga synder, men också hur bilderna avspeglar tidens hållning till kropp, kön och sexualitet.

Bildmaterialet har sökts via större fotosamlingar, huvudsakligen i Rom och Bologna. Jag har också besökt ett stort antal kyrkor och kloster runtom i Italien för att studera väggmålningar där frestelsemotivet fanns. Verken som ingår i studien är av mycket skiftande konstnärlig kvalité. En del är utförda av de mest hyllade konstnärerna för tiden, som Jacopo och Domenico Tintoretto, Paolo Veronese, Ludovico Carracci och Simon Vouet. Klostermålningarna är i sin 
tur målade av lokala förmågor eller mindre konstnärligt begåvade munkar. De är inga mästerverk, man jag har valt att se förbi konstnärliga kvalitéer och har sökt mitt material på en bred front. Detta för att på ett mer tillfredställande sätt kunna redogöra för frestelsemotivet förekomst och för att se vem som beställde motiven, var dessa bilder distribuerades och uppfördes, och vem de skapades för. De undersökta bilderna är utförda i en rad olika typer av tekniker och material. De består av oljemåleri, teckningar, grafik, frescomåleri och skulptur.

Frestelsetemat har fått en begränsad uppmärksamhet i den tidigare konstvetenskapliga forskningen. Möjligtvis har helgonens könsliv, eller snarare avsaknaden av ett sådant, ansetts vara ett tabubelagt ämne. Motiven är dock inte helt ovanliga: De återfinns i illustrationerna till helgonbiografier, de framställs i altartavlor i kyrkor, i utsmyckningar av privata gravkapell, i väggmålningar i kloster. De såldes som grafik på den öppna konstmarknaden och beställdes till privata konstsamlingar. Kort sagt, frestelsemotivet fanns överallt där religiösa bilder fanns. Det visar att scenerna som avbildade manliga helgons kamp mot det köttsliga begäret inte bara producerades i en ökad mängd, utan också riktades till en relativt bred grupp där både prästerskap och lekmän ingick.

Det sena 1500-talets och 1600-talets bildkonst var starkt påverkad av både den protestantiska och den

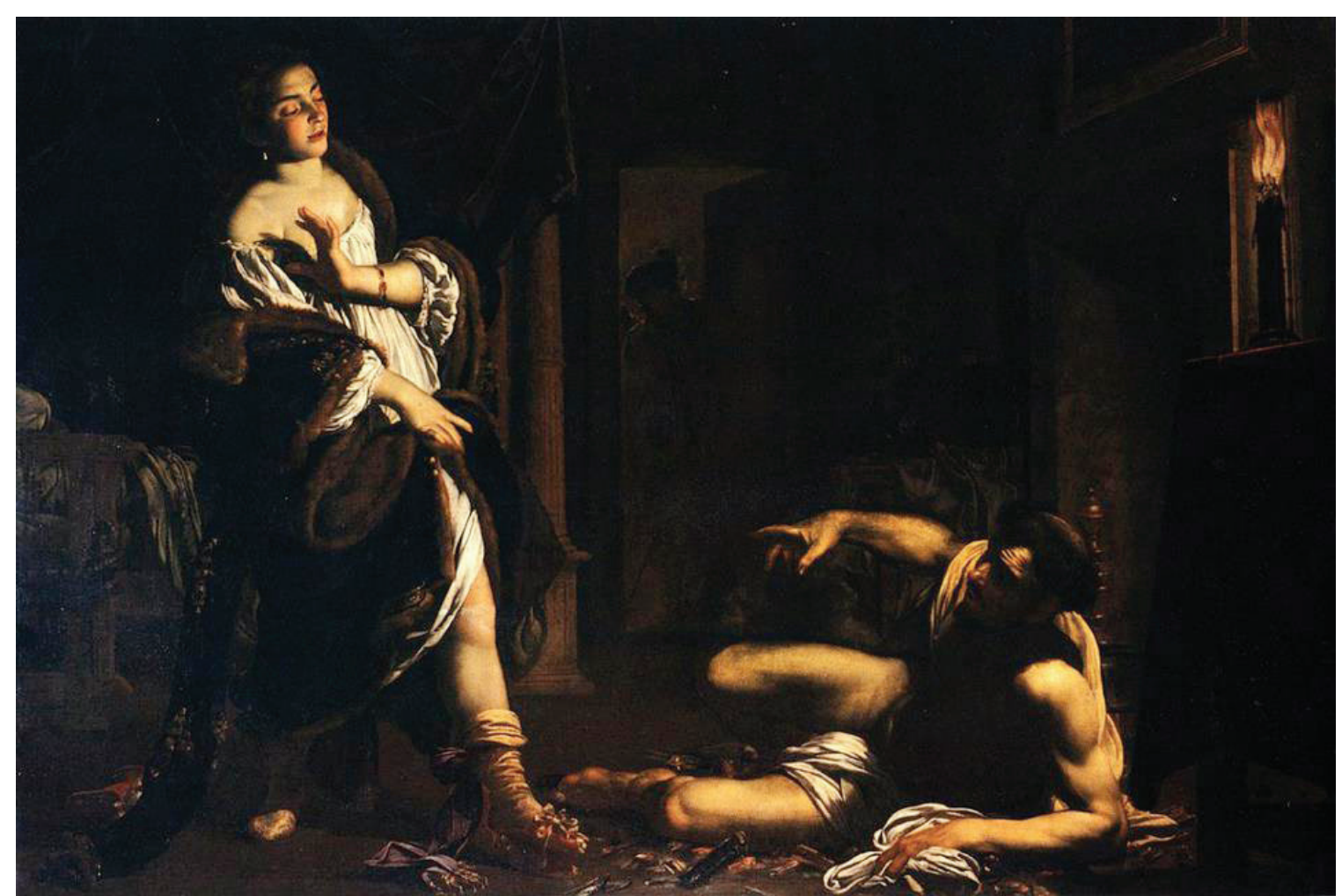

\section{Bild 1: Simon Vouet, Sankt Franciskus exemplariska kyskhet, 1624. Olja på duk, San Lorenzo in Lucina, Rom.}

katolska reformationen. Inom konstvetenskapen har man ofta lyft fram den katolska kyrkans striktare regler för vad som kunde anses sedligt i den religiösa bildkonstens motivframställningar. Dessa diskuterades nämligen kort och i ganska allmänna ordalag alldeles i slutet av det 18 år långa konciliet. Där fastslogs också att avbildningar av helgon och andra heliga personer fyllde en viktig funktion. De stärkte betraktarens religiositet och försåg folket med goda förebilder. Det ökade intresset för helgonbilder kan också ses som en förklaring till frestelsemotivets stigande popularitet under perioden. 
Den konstvetenskapliga forskningen har dock ofta förbisett hur den visuella kulturen påverkades av det Tridentinska konciliets regler gällande sexuell decorum och inte minst det dekret som fastställde det prästliga celibatets betydelse. Jag menar att frestelsemotivet är intimt sammankopplat med den katolska kyrkans förhärligande av oskuld och sexuell avhållsamhet. För trots att könsumgänge mellan två makar uppmuntrades, äktenskapet var likväl ett sakrament, alltså heligt och av gud instiftat, upphöjdes celibatet som det mest respektabla levnadssättet.

Kyskhetens höga status aktualiserades på nytt $\mathrm{i}$ samband med reformationen och efter att protestanterna börjat uppmana sina präster att gifta sig. När katolikerna valde att behålla det obligatoriska prästliga celibatet, underströks dess betydelse och anknytning till de heliga skrifterna. Ofta användes den sexuella avhållsamheten som ett exempel på, att man till skillnad från protestanterna eftersträvade ett dygdigt liv. Det var dock inte helt oproblematiskt, eftersom protestanternas kritik av den katolska kyrkan till stor del riktades just mot de ledande skiktens syndiga leverne och inte minst mot den otukt som bedrevs i prästliga och även påvliga sängar. Kritiken var befogad. Vid tiden för den katolska reformationens inledande, 1545, levde nästan var tredje katolsk präst på den italienska halvön öppet med en älskarinna, och ofta hade de barn tillsammans.
Det blev nu av ytterst stor vikt att rensa ut i leden. Fördömandet av de präster som fortsatte sitt syndiga leverne var hårt. Den som vägrade lämna sin älskarinna och den familj han avlat med denna, straffades med livslång uteslutning ur kyrkan.

Den moraliska kontrollen av befolkningen tog sig uttryck genom understrykandet av vikten att bikta sina synder, framförallt när det gällde köttsliga sådana. Ansvaret att identifiera sina illgärningar och laster lades nu, i betydligt större utsträckning än tidigare, på den biktande, då prästen uppmanades att inte ställa personliga frågor. Michel Foucault lyfter fram denna företeelse som avgörande i den mänskliga sexualitetens historia. För första gången i historien uppmanades människor att ärligt och öppenhjärtligt beskriva sina sexuella synder och handlingar. Den ökade verbalisering av sexuella synder skapade en efterfrågan på bilder där ett föredömligt och kyskt beteende uppvsiades. Här fyller frestelsemotiven således en viktig funktion. De avbildade helgonen visade att det istället för att leva i synd, var möjligt och eftersträvnadsvärt att aktivt motstå det köttsliga begäret - det vill säga kvinnan.

Redan i ett tidigt skede kunde jag konstatera att de frestade kvinnliga helgonen lyste med sin frånvaro i bildkonsten --trots att de förekommer i den skriftliga traditionen. En trolig förklaring är att en bild av en sexuellt frestad helig kvinna inte skulle ansetts sedlig. Flertalet av de kvinnliga helgonen vars köttsliga lidel- ser beskrivs i heliga skrifter, tillhörde en grupp av före detta prostituerade, de så kallade heliga skökorna. De var alltså kvinnor som till skillnad från de heliga männen redan fallit för frestelsen mer än en gång. Att framställa dem lockade till ytterligare synd av unga vackra män, skulle därför knappast understryka deras kyskhet. Avsaknaden av kvinnliga helgons frestelsescener visar att den idealiska kyskheten bäst framställs genom en manlig kropp. Frestelsemotivet utgör därmed en utmärkt möjlighet att undersöka konstruktionen av en föredömlig manlighet som kontrasteras mot den oheliga kvinnan.

Inledningsvis var detta forskningsprojekt tänkt att bli en feministisk studie där huvudfokus låg på den bildliga framställningen av den kvinnliga fresterskan inom den katolska religionskulturen. Ganska snart insåg jag dock att denna infallsvinkel redan var relativt utforskad och därmed mindre intressant. Mitt intresse började istället allt mer att riktas mot den heliga mannen. Han som stod emot, och som på så vis förhärligade oskulden och vikten av den sexuella avhållsamheten som så ivrigt förespråkades av den nyreformerta katolska kyrkan.

Ofta är fresterskorna i bilderna sensuella, ibland rentav erotiskt framställda. Det väcker naturligtvis frågan om förevisningen av den heliga mannens kyskhet, i själva verket var ett svepskäl för att ostört få studera avbildningar av attraktiva kvinnor. 
Jag hävdar dock att den kvinnliga skönheten fyller en viktig funktion i framlyftandet av den heliga mannens kyska karaktär. För han motstod henne ju, trots att hon var attraktiv. Betraktaren uppmanades att lära sig att göra detsamma.

I frestelsescenerna framställs alltså det nya katolska mansidealet.

Bilderna föreställer inte några impotenta veklingar. Konstnärerna lyfte istället fram heroiska, ofta muskulösa och kraftfulla män som motstår den frestande kvinnan, inte för att de var oförmögna till könssamvaro, utan för att de visste att gudskärleken var högre än den jordiska. I bildernas textkällor framgår att männen efter att de lyckats motstå sina köttsliga begär av Gud belönades med total avsaknad av sexuell lust. En ideal tillvaro de flesta män bara kunde drömma om att uppnå.

Avhandlingen är geografiskt koncentrerad till Italien. Denna avgränsning kan motiveras av närheten till påvestaten Rom. Bilderna som utfördes på den Italienska halvön under 1600-talet var starkare påverkade av det Tridentinska konciliets uppdaterade moralregler. Frestelsetemat förekom dock inom bildkonsten även i andra delar av det katolska Europa och i den nya världen dit inte minst jesuiterna och franciskanerna reste för att missionera. Studiet av frestelsemotivet bör alltså inte sluta här. Min avhandling kan snarare ses som en introduktion till detta fascinerande forskningsområde.
Minna Hamrin är sedan 2014 doktorand vid den konstvetenskapliga institutionen vid Åbo akademi. Hon utexaminerades med magisterexamen vid åmnet 2009. Hamrin har under sina forskningsstudier varit utbytestforsBild 2: Okänd konstnär, Sankt Franciskus karstuderande vid Bologna Univerexemplariska kyskhet, 1700-talets mitt. Fresco, Convento di beato Giacomo, Bitetto (Apulien). sitet, Italien låsåret 2013/2014 och storstipendiat vid det svenska institutet i Rom låsåret 2015/2016.

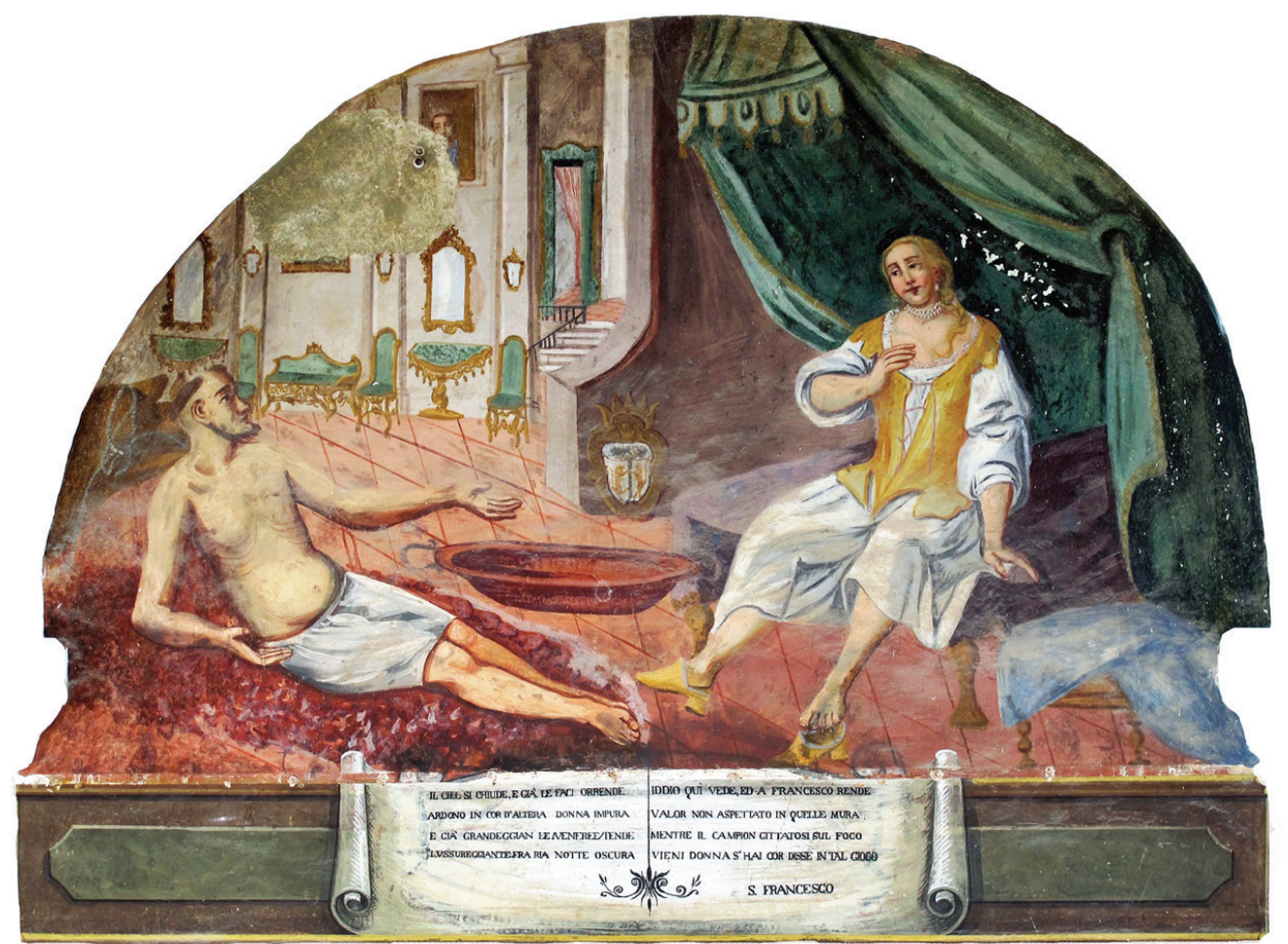

